\title{
Basic FGF Reverses Chemical and Morphological Deficits in the Nigrostriatal System of MPTP-Treated Mice
}

\author{
Dörte Otto and Klaus Unsicker \\ Philipps-University, Department of Anatomy and Cell Biology, D-3550 Marburg, Federal Republic of Germany
}

\begin{abstract}
The specific mechanisms underlying the restorative effects of adrenal chromaffin grafts in experimental parkinsonism are still obscure. Recent findings indicated an involvement of graft-induced trophic interactions in the course of recovery-related events. Evidence that basic fibroblast growth factor (bFGF), a potent trophic protein for neurons, (1) is present in chromaffin cells (Blottner et al., 1989) and (2) exerts trophic activities on embryonic mesencephalic neurons in vitro (Ferrari et al., 1989) provided the rationale for administering bFGF in gel foam implants unilaterally to the striatum of 1-methyl-4-phenyl-1,2,3,6-tetrahydropyridine (MPTP) lesioned mice. Simultaneous bFGF/MPTP treatment diminished bilaterally the reduction of striatal dopamine (DA) levels observed in cytochrome c/MPTP-treated mice and led to an ipsilateral reappearance of tyrosine hydroxylase (TH)like immunoreactive fibers, most notably adjacent to the implant, 2 weeks after the surgery. Determinations of TH activities and TH immunoblotting demonstrated that bFGF almost fully reversed the loss of TH activity on either side but restored TH protein more on the ipsilateral than on the contralateral side. Furthermore, differences in dihydroxyphenylacetic acid levels, which were about twice as high on the contralateral side yet still reduced with respect to untreated mice, supported our assumption that the molar TH activity was increased on the untreated side, possibly due to an intrinsic compensatory up-regulation. Delayed administration of bFGF starting $8 \mathrm{~d}$ after the MPTP treatment was equally effective with regard to morphological parameters. Our results suggest that bFGF partially prevents the deleterious chemical and morphological consequences of an MPTP-mediated nigrostriatal lesion. Thus, bFGF mimics at least the morphological effects of chromaffin cell grafts to the MPTPlesioned brain.
\end{abstract}

Grafting fetal neural tissue into the mammalian brain to promote functional recovery of damaged neuronal circuitries has received increasing attention in recent years. In animal models, it has been repeatedly confirmed that grafting may counteract the consequences of brain lesions, degenerative changes, and

\footnotetext{
Received May 2, 1989; revised Dec. 7, 1989; accepted Jan. 10, 1990.

We wish to thank Heidi Hlawaty for excellent technical assistance. We are indebted to Dr. Irina Wulle for indispensable advice and valuable discussions. This work was supported by grant UN 34/13-1 from the German Research Foundation.

Correspondence should be addressed to Dörte Otto, Philipps-University, Department of Anatomy and Cell Biology, Robert-Koch-Str. 6. D-3550 Marburg. FRG.

Copyright 1990 Society for Neuroscience $0270-6474 / 90 / 061912-10 \$ 02.00 / 0$
}

neuroendocrine disorders or reverse behavioral deficits (Dunnett et al., 1983; Stenevi et al., 1984; Gibson and Krieger, 1985).

Parkinson's disease is regarded as a dopamine (DA) deficiency syndrome (Bernheimer et al., 1973) resulting from the degeneration of the nigrostriatal DA system. In animal models of Parkinson's disease, transplantation of fetal substantia nigra has been employed as a means for providing a new dopaminergic input to the host striatum (Perlow et al., 1979; Dunnctt ct al.. 1981, 1983). An analogous approach to compensate for the depletion of DA is the grafting of pieces or cell suspensions of adrenal medulla into the lateral ventricles (Freed et al., 1981; Becker and Freed, 1988) or directly into the striatum (PatelVaidya et al., 1985; Strömberg et al., 1985; Freed et al.. 1986). Although the intrastriatal chromaffin grafts show modest survival (Freed et al., 1986; Bohn et al., 1987; Hansen et al., 1988; Pezzoli et al., 1988), they can ameliorate behavioral impairments in the DA-denervated rat striatum (Freed et al.. 1981; Strömberg et al., 1985) and enhance the regeneration of the dopaminergic host system in l-methyl-4-phenyl-1,2,3,6-tetrahydropyridine (MPTP)-treated mice and monkeys (Bohn et al., 1987; Fiandaca et al., 1988). There is as yet no conclusive explanation with regard to the mechanisms responsible for the curative effects described above. Mechanisms other than the. probably insufficient, release of DA by the graft (Freed et al., 1983; Strömberg et al., 1984) as, for example, liberation of trophic factors and inflammation-related events have been implicated in the beneficial effects of the grafts (Bohn et al., 1987: Fiandaca et al., 1988; Pezzoli et al., 1988).

The chromaffin cell has been shown to store and release varjous neurotrophic activities (Unsicker et al., 1987a, 1989). One of its more comprehensively studied neurotrophic proteins is basic fibroblast growth factor (bFGF). bFGF has been characterized as a $16-18 \mathrm{kDa}$ protein with mitogenic properties for mesenchyme derived cells (Lobb and Fett, 1984). More recently, bFGF has been found to possess neurotrophic activities for several central and peripheral neuron populations in vitro (Morrison et al., 1986; Walicke et al., 1986; Unsicker et al., 1987b) and in vivo (Otto et al., 1987, 1989; Anderson et al., 1988; Blottner et al., 1989). bFGF has been isolated from adrenals (Gospodarowicz et al., 1986), and there is evidence that immunoreactive bFGF is specifically enriched in chromaffin vesicles (Westermann et al., 1990). These findings, along with the isolation of a striatal-derived neurotrophic factor (SDNF; Dal Toso et al., 1988) which shows striking biochemical similarities to bFGF, formed the basis for our hypothesis that adrenomedullary bFGF may be instrumental in fostering recovery associated with adrenal medulla grafts in animal models of parkinsonism. 
MPTP is known to produce a transient neurotoxicity in the nigrostriatal dopaminergic system of young adult mice (Heikkila et al., 1984; Hallmann et al., 1985; Ricaurte et al., 1986) and represents a useful tool to study experimental parkinsonism. The extent and intensity of the damage, as well as the evolution of recovery, are dependent on the dose and protocol of MPTP application (Langston and Irwin, 1986; Marsden and Jenner, 1987).

In the present study we tried to mimic the effects of adrenal medulla grafts in MPTP-damaged C57BL/6 mice on the host dopaminergic system by administering bFGF via a gel foam implant. The recovery 2 weeks after MPTP treatment was assessed by tyrosine hydroxylase (TH) immunocytochemistry and by determining biochemical parameters of the dopaminergic system in the striatum.

\section{Materials and Methods}

\section{MPTP treatment}

Young adult male C57BL/6 mice (Charles River Wiga, Sulzfeld, FRG) received 3 intraperitoneal injections of $30 \mathrm{mg} / \mathrm{kg}$ MPTP hydrochloride (Sigma) dissolved in $0.5 \mathrm{ml}$ of $0.9 \%$ saline adjusted to $\mathrm{pH} 7.4$ at $24 \mathrm{hr}$ intervals. The first injection was given at the day of surgery or, for a delayed application of factors (see below), $8 \mathrm{~d}$ before the surgery. Control mice received injections of saline according to the same protocol.

\section{Animal surgery}

For studying the effects of bFGF on the lesioned dopaminergic system, the administration via a gel foam implant turned out to yield the most reproducible results. Under deep anesthesia $(0.3 \mathrm{ml}$ of $3.5 \%$ chloralhydrate), the skull of the right hemisphere was trepanated at a circumscribed area and the cortex covering the middle part of the striatum was removed by aspiration. When the bleeding had ceased, the gel foam implant (see next section) was placed into a prepared small cavity within the striatal parenchyme. The cortical wound cavity was filled with a piece of untreated gel foam before the skin was sutured. All animals had postoperative survival times of 2 weeks.

\section{Administration of factors}

Sterile pieces of gel foam (Spongostan, Ferrosan, Denmark; approx. 2$3 \mathrm{~mm}^{3}$ ) served as implants and contained the following proteins dissolved in saline: (1) $4 \mu \mathrm{g}$ cytochrome c (Serva) as a nontrophic control protein and (2) $4 \mu \mathrm{g} b F G F$. Bovine recombinant bFGF was a generous gift of Dr. Knoerzer (Progen, Heidelberg, FRG). Its biological activity was tested in a neuronal survival assay (Unsicker et al., 1987b) and amounted to 3 trophic units (TU)/ng protein. As shown previously, the full quantity of factor contained in the gel foam could be eluted after $12 \mathrm{hr}$ and retaincd its biological activity in an in vitro assay system (Otto et al., 1989).

\section{Quantitative determinations of $D A, D O P A C$, and TH activity}

Mice were killed by decapitation, and the striatum was rapidly dissected on ice. After weighing, the tissue was homogenized in $300 \mu 120 \mathrm{~mm}$ sodium acetate buffer with $0.1 \%$ Triton-X-100. An aliquot was processed for analysis of DA and its metabolite dihydroxyphenylacetic acid (DOPAC), respectively. The remaining homogenate was taken for measurements of TH activities and immunoblot analysis.

$D A$ and DOPAC measurements. A $100 \mu \mathrm{l}$ aliquot was added to 900 $\mu \mathrm{l}$ of $0.1 \mathrm{M}$ sodium acetate buffer containing $1 \%$ Triton-X-100, $25 \mathrm{~mm}$ ethylenediaminotetraacetic acid (EDTA), and, as internal standard, $\mathrm{N}$-methyl-dopamine. Following deproteinization with $50 \mu \mathrm{l} \mathrm{HClO}_{4}(70 \%)$ and centrifugation, $100 \mu \mathrm{l}$ of the supernatant were processed by alumina extraction in triplicate. DA and DOPAC were detected by HPLC-ED ( $\mu$-Bondapack-C18 column, $10 \mu \mathrm{m}$ particle size; Waters system with pump 510; sample processor 740; Metrohm amperometric detector with glassy carbon electrodes at a potential of $0.72 \mathrm{~V}$ against a $\mathrm{Ag} / \mathrm{AgCl}$ reference electrode) and quantified by comparison to the internal standard. Elution was performed with $50 \mathrm{mM} \mathrm{HClO}_{4}$ containing $25 \mathrm{~mm}$ EDTA at a flow rate of $1.0-1.2 \mathrm{ml} / \mathrm{min}$.

TH activities. After centrifugation for $5 \mathrm{~min}\left(10,000 \times g\right.$ at $\left.6^{\circ} \mathrm{C}\right)$, a $100 \mu \mathrm{l}$ aliquot was gel-filtrated at $6^{\circ} \mathrm{C}$ using a Sephadex-G-25 column
(Müller and Unsicker, 1981). Fifty microliters of the protein eluate were incubated for $30 \mathrm{~min}$ at $37^{\circ} \mathrm{C}$ with $50 \mu \mathrm{l}$ of a reaction mixture containing $0.17 \mathrm{~mm}$ L-tyrosine, $0.004 \mathrm{~mm}$ catalase, $0.025 \mathrm{~mm}$ o-benzylhydrazine, $0.19 \mathrm{~mm}$ 6,7-dimethyl-5,6,7,8-tetrahydropterine, $0.24 \mathrm{~mm}$ ascorbic acid, and $0.2 \mathrm{M}$ sodium acetate buffer, $\mathrm{pH}$ 6.0. Control samples were boiled for $10 \mathrm{~min}$. Reactions were terminated with $50 \mu \mathrm{l}$ of $70 \% \mathrm{HClO}_{4}$; adrenaline was added as an internal standard, and the samples were centrifuged for $5 \mathrm{~min}$ at $10,000 \times g$ at $6^{\circ} \mathrm{C}$. The enzymatically formed Dopa was extracted and quantified using the same procedure as for the DA measurements (see above).

\section{TH immunocytochemistry}

Chloralhydrate-anesthetized mice (naive, $n=3$; MPTP, $n=4$; MPTP/ cytochrome c, $n=6$; MPTP/bFGF, $n=9$; MPTP/bFGF delayed, $n=$ 4) were perfused transcardially with a fixative containing $4 \%$ formaldehyde- $-0.2 \%$ picric acid in $0.1 \mathrm{M}$ phosphate buffer $(\mathrm{PB})$ at $4^{\circ} \mathrm{C}$. Twentyfive-micron-thick frontal sections of the striatum were cut on a cryostat; every fifth section was washed in several changes of $0.1 \mathrm{M} P B$ and further processed. Immunoperoxidase staining was performed with free-floating sections. Following preincubation, the sections were incubated with (1) anti-TH serum (Eugene Tech, Allendale; $1: 100$ ) for $12 \mathrm{hr}$ at $4^{\circ} \mathrm{C},(2)$ anti-rabbit $\mathrm{IgG}$ (Sigma; $1: 20$ ) for $45 \mathrm{~min}$ at $20^{\circ} \mathrm{C}$, and (3) peroxidaseantiperoxidase (PAP) complex (Sigma; 1:50) for $45 \mathrm{~min}$ at $20^{\circ} \mathrm{C}$. The tissue bound peroxidase was visualized by using diaminobenzidine as enzyme substrate. In control experiments, the primary antiserum was replaced by normal rabbit serum.

\section{TH immunoblotting}

Aliquots of the striatal homogenate (see above) were resolved by SDSPAGE according to Laemmli (1970). An aliquot of one animal was applied per lane, the protein content in all lanes being identical for each blot. Protein was determined by measuring the absorption at $280 \mathrm{~nm}$. Separated proteins were electrophoretically transferred onto nitrocellulose filters (Towbin et al., 1979), and blots were incubated with $\mathrm{TH}$ antiserum (see above) and peroxidase-conjugated second antibodies as described by Hawkes et al. (1982). The TH immunoblotting was performed with 4 different sets of samples.

\section{Cell culture}

Ciliary ganglia (CG) were dissected from 8-d-old chick embryos and dissociated into single cells according to published procedures (Unsicker ct al., 1987b). About 200,000 cells were preplated for $1.5 \mathrm{hr}$ in $2 \mathrm{ml}$ of DMEM (Dulbecco's Modified Eagles Medium; Gibco) and 10\% fetal calf serum (FCS; Flow) on $35 \mathrm{~mm}$ Falcon petri dishes. The enriched neuron suspension ( $>90 \%$ ) was seeded onto 96 well microtiter plates (Falcon) coated with poly-L- $\alpha$-ornithine (PORN)-laminin (gift of Dr. Mollenhauer, University of Erlangen, FRG) with a density of about 1000 neurons/well. Cultures were grown in DMEM with $0.25 \% \mathrm{BSA}$ (Serva) and N1 additives (Bottenstein et al., 1980) for $24 \mathrm{hr}$. Plateau survival was established by supplementation of a saturating concentration of bFGF $(10 \mathrm{ng} / \mathrm{ml})$.

The gel foam implants were removed from all mice taken for biochemical analysis and frozen at $-80^{\circ} \mathrm{C}$. For testing the biological activity contained in the wound fluid, each gel foam was eluted in $100 \mu \mathrm{l}$ DMEM at $4^{\circ} \mathrm{C}$ overnight, and the eluate was centrifuged at $1000 \mathrm{rpm}$ for 10 min to remove cellular debris. The supernatant was tested in $25 \mu \mathrm{l}$ aliquots per start well and titrated over 12 wells. Anti-bFGF-IgG (antibFGF antiserum was kindly provided by Dr. Böhlen; Pearl River, NY) recognizing bovine and rat bFGF were employed in a final dilution sufficient to block the activity of $40 \mathrm{ng} / \mathrm{ml}$ bFGF on CG neurons. Twenty-four hours after seeding, the cultures were fixed with $2.5 \%$ glutaraldehyde in $\mathrm{PB}$, and surviving neurite-bearing neurons were counted.

\section{Results}

\section{Striatal DA levels}

To exclude that DA levels on the side of implantation (right) were reduced as a consequence of the surgery, mice were imInediately decapitated after the operation and the striata separately processed for DA determination. A slight reduction was observed on the operated side, yet by 2 weeks DA levels (Table 1) were found to have returned to normal on this side and 
Table 1. Effects of gel foam implants to the right striatum on striatal DA levels in MPTP-treated mice

\begin{tabular}{|c|c|c|c|c|}
\hline \multirow{2}{*}{\multicolumn{2}{|c|}{ Treatment }} & \multirow[b]{2}{*}{$n$} & \multicolumn{2}{|c|}{ Dopamine (ng/mg tissue) } \\
\hline & & & Right & Left \\
\hline \multicolumn{2}{|l|}{ None } & 6 & $10.43 \pm 0.86$ & $11.49 \pm 0.39$ \\
\hline- & cytochrome c & 4 & $10.37 \pm 0.36$ & $13.87 \pm 0.78$ \\
\hline- & cytochrome c & 5 & $8.9 \pm 0.49$ & $10.58 \pm 0.38$ \\
\hline MPTP & - & 7 & $2.71 \pm 0.29$ & $2.79 \pm 0.26$ \\
\hline \multicolumn{2}{|c|}{ MPTP + cytochrome c } & 4 & $2.4 \pm 0.37$ & $2.4 \pm 0.64$ \\
\hline \multicolumn{2}{|c|}{$\mathrm{MPTP}+4 \mu \mathrm{g} \mathrm{bFGF}^{a}$} & 7 & $4.69 \pm 0.36$ & $4.48 \pm 0.16$ \\
\hline
\end{tabular}

Gel foam was soaked with the indicated factors. The mice were killed 2 weeks after the surgery except for the group marked with one asterisk (*), which was killed immediately and analyzed for DA levels. Results are given as means \pm SEM.

${ }^{a} p<0.01$ compared to data from MPTP/cytochrome c-treated mice (2-sided $t$ test after analysis of variance).

slightly, but not significantly, to be elevated on the nonoperated side. Mice treated with cytochrome $\mathrm{c}$ without MPTP served as control group (100\%).

Treatment with MPTP caused an $80 \%$ reduction of striatal DA levels in mice that had carried a cytochrome $c$ implant for 2 weeks. This reduction was identical to that seen in unoperated MPTP-treated mice and lasted for at least 4 weeks (data not shown). Treatment with bFGF diminished this reduction significantly $(p<0.01)$ to $55 \%$ on the ipsilateral side and to $68 \%$ on the contralateral side. Absolute DA levels were equal on either side.

Eight days after MPTP treatment, DA content was diminished to $84 \%$ of controls $(1.92 \pm 0.51 \mathrm{ng} \mathrm{DA} / \mathrm{mg}$ tissue; $n=5)$. Thus, the completeness of the MPTP lesion has been verified before administering $\mathrm{bFGF}$ in a delayed regimen.

\section{TH immunocytochemistry}

By 1 and 2 weeks the dense network of very fine TH-like immunoreactive (TH-IR) fibers visible in untreated mice (Fig. $1 a$, b) had virtually disappeared in the striata of the MPTP/cytochrome $c$ treated group (Fig. $1 c, d$ ). The elevation of DA content due to bFGF application was paralleled by a notable reappearance of TH-IR fibers in the right, but not in the left striatum (Fig. 2). The fiber density was especially high close to the implant within a zone of 150-200 $\mu \mathrm{m}$ (Fig. 2a) and decreased farther away from it (Fig. 2b). In most animals we observed an increase in the TH fiber diameter adjacent to the bFGF-containing implant. The left striatum displayed sparse or no TH-IR fibers, which was, at first sight, not easily reconciled with DA levels paralleling those on the contralateral side. Explanations might be sought in discrepant TH immunoreactivity and synthetic activity (see next section and Discussion). Delayed application of bFGF a week after initiation of the MPTP lesion led to an identical TH-IR fiber pattern ( $c f$. Fig. 2), suggesting that bFGF is, in fact, capable of partially restoring a normal dopaminergic striatal innervation.

\section{Striatal TH activity, DOPAC levels, and TH immunoblotting}

The finding that the striatal DA content could be restored to the same extent on both sides following unilateral bFGF application in MPTP-treated mice, although TH-IR fibers were only detectable on the ipsilateral side, pointed at different activities of the rate-limiting enzyme of the DA synthesis, i.e., TH. There-
Table 2. Striatal TH activities 2 wecks after implantation of gel foam containing cytochrome $c$ or bFGF to the right striatum of MPTP-treated mice

\begin{tabular}{llll} 
& & \multicolumn{2}{l}{ ng Dopa/mg tissue/30 min } \\
\cline { 3 - 4 } Treatment & $n$ & Right & Left \\
\hline None & 4 & $31.39 \pm 2.75$ & $32.99 \pm 3.15$ \\
MPTP + cytochrome c & 3 & $17.61 \pm 1.65$ & $16.33 \pm 0.63$ \\
MPTP $+4 \mu$ g bFGF & 4 & $32.94 \pm 2.94$ & $28.52 \pm 1.29$ \\
\hline
\end{tabular}

Results are given as means \pm SEM.

fore, we examined striatal TH activity, TH protein amounts, and levels of the DA decomposition product DOPAC. Analysis of these parameters allowed us to specify side differences in the DA metabolism.

TH activity. Determinations of the TH activity, as assessed by quantification of formed Dopa during $30 \mathrm{~min}$ of incubation, revealed a bilateral depletion of about $50 \%$ in MPTP/cytochrome c-treated mice as compared to controls (Table 2). This depletion was nearly fully reversed in MPTP/bFGF-treated animals, the activity on the side of treatment being only slightly higher than on the contralateral side.

TH immunoblotting. We used TH immunoblots of striatal homogenates for demonstrating in a semiquantitative manner different amounts of TH protein. A representative blot is shown in Figure 3. In comparison to control mice, the TH amount appeared to be considerably reduced in MPTP/cytochrome c-treated mice as visualized by the width of the TH bands (Fig. 3 , lanes 1 and 2). Administration of bFGF apparently restored TH protein amounts on the ipsilateral side more than on the untreated side (Fig. 3, lanes 4 and 3), where the TH protein amount appeared to be comparable to that of MPTP/cytochrome c-treated mice. Hence, the side variances in the TH protein amounts correlated with those observed with immunocytochemical methods (Figs. 1, 2).

DOPAC levels. In MPTP/cytochrome c-treated mice, DOPAC levels were depleted below the detection limit on either side (Table 3). bFGF application increased the ipsilateral DOPAC content to about $25 \%$ of control levels. However, in the contralateral striatum, DOPAC levels were found to be twice as high, suggesting an elevated DA turnover.

\section{In vitro neurotrophic activities}

Figure 4 demonstrates the capacity of neurotrophic activities eluted from gel foam implants containing cytochrome c or bFGF, respectively, to promote the survival of cultured embryonic chick CG neurons. The eluates from either source maintained identical numbers of neurons as a saturating concentration of bFGF. However, addition of anti-bFGF antibodies in amounts sufficient to block $40 \mathrm{ng}$ bFGF failed to reduce the survival and neurite-promoting activity eluted from the implants.

\section{Discussion}

The neurotoxin MPTP generates clinical symptoms and neuropathological changes in humans which closely resemble Parkinson's disease (Ballard et al., 1985; Burns et al., 1985). Similarly, primates and certain rodents are susceptible to MPTP and develop, at least transiently, characteristic neurodegenerative changes within the nigrostriatal system (Burns et al., 1983; Heikkila et al., 1984; Jenner et al., 1984). In young adult mice, 


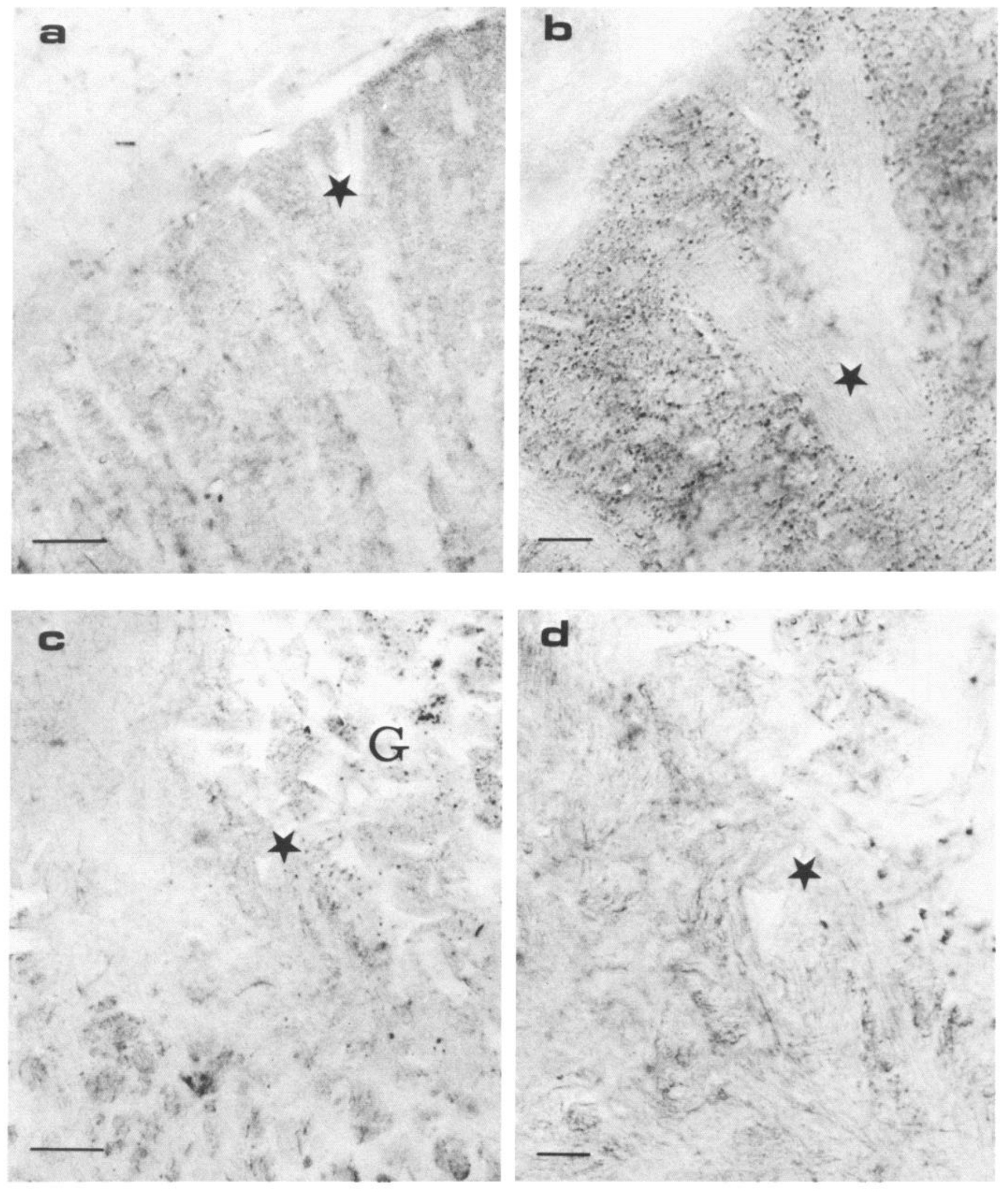

Figure 1. $a$, Peroxidase immunostaining of TH in the striatum of a naive mouse. $C$, corpus callosum. $b$, Distinct TH-IR fibers are visible as very fine spot-like structures only at higher magnification. $c$ and $d$, One and two weeks after MPTP treatment, TH-IR in the striatum of mice carrying a cytochrome c gel foam implant $(G)$ had disappeared. In $c$ and $d$, there is some unspecific staining of nerve fiber bundles, and within the gel foam peroxidase-containing cells are visible as dark structures. Scale bar: $a$ and $c, 100 \mu \mathrm{m} ; b$ and $d, 25 \mu \mathrm{m}$. 


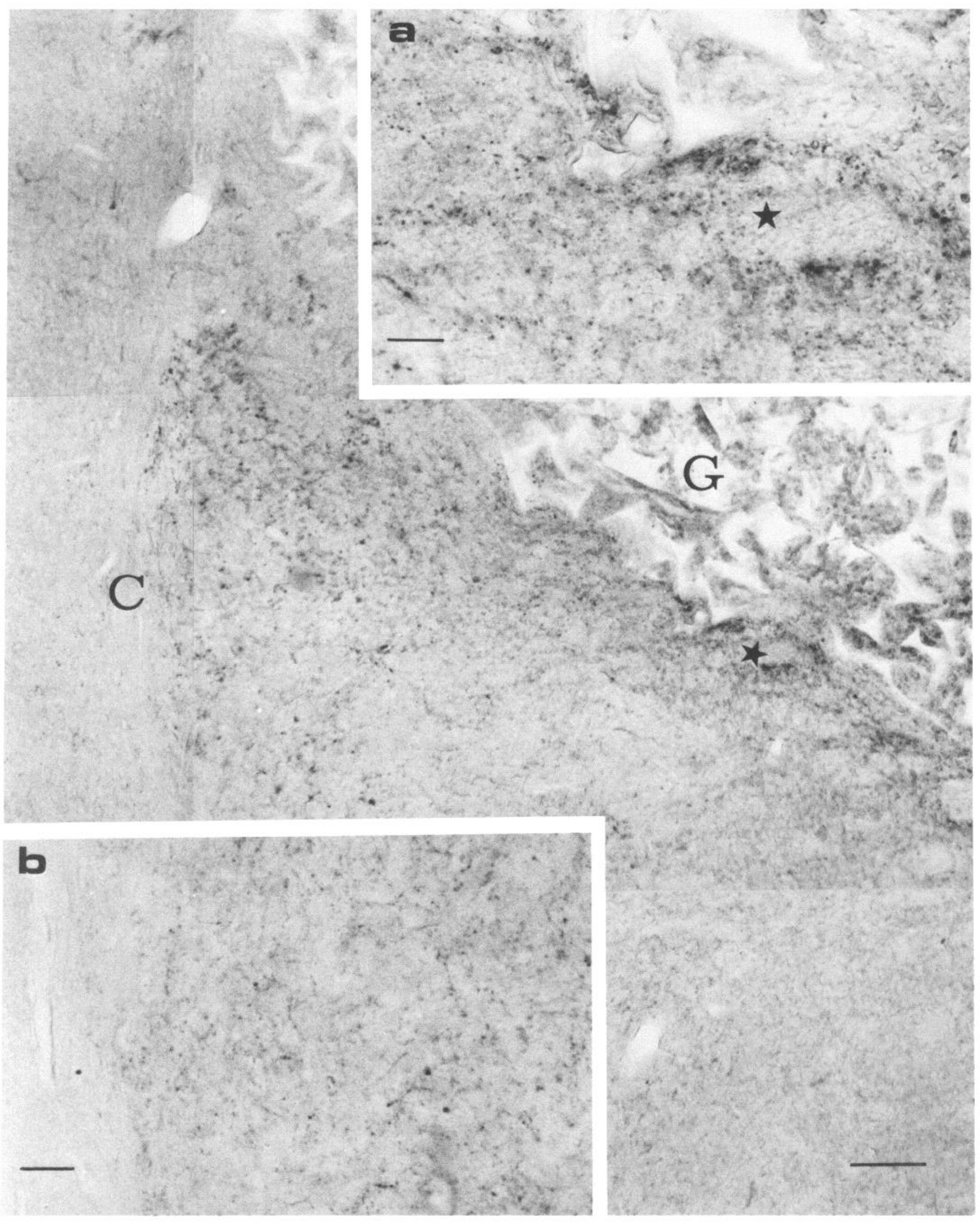

Figure 2. A bFGF-containing piece of gel foam $(G)$ transplanted to the right striatum of a MPTP-treated animal 2 weeks after initiating the lesion. Insets depict areas close $(a)$ and farther away $(b)$ from the implant at higher magnification. Note the restoration $(c f$. Fig. $1 c, d)$ of the TH-IR fibers extending from the surface of the implant towards the corpus callosum $(C)$ and within a 150 - to $200-\mu \mathrm{m}$-wide zone along the interface between implant and striatum. No recovery was observed on the contralateral side. Scale bar, $100 \mu \mathrm{m}$ (insets, $25 \mu \mathrm{m}$ ). 
Table 3. Striatal levels of DOPAC, a major DA metabolite, 2 weeks after MPTP treatment and implantation of gel foam soaked with cytochrome c or bFGF

\begin{tabular}{llll} 
& & \multicolumn{2}{c}{ DOPAC $(\mathrm{pg} / \mathrm{mg}$ tissue $)$} \\
\cline { 3 - 4 } Treatment & $n$ & Right & Left \\
\hline None & 4 & $203.64 \pm 9.06$ & $192.95 \pm 16.21$ \\
MPTP + cytochrome c & 4 & n.d. $^{a}$ & n.d. \\
MPTP $+4 \mu \mathrm{g}$ bFGF & 4 & $54.75 \pm 10.73$ & $95.15 \pm 13.27$
\end{tabular}

Results are given as means \pm SEM.

a Not detectable.

MPTP treatment preferentially damages nerve endings, leaving the majority of cell bodies in the substantia nigra unaffected (Heikkila et al., 1984; Gupta et al., 1986; Ricaurte et al., 1986). Extent and time course of the MPTP-induced damage are well documented in the C57BL/6 strain (Sundström et al., 1987, 1988). These conditions offer the possibility for studying the influence of specific factors on the recovery of the dopaminergic nigrostriatal system.

Implantation of gel foam into the striatum generated an insignificant reduction of ipsilateral DA content immediately after the surgery, which returned to control levels by 2 weeks. The contralateral DA content was slightly increased above control levels. This observation already underscores the remarkable compensatory mechanisms (Hefti and Weiner, 1988) and plasticity (Björklund and Stenevi, 1979) of the central dopaminergic system. The administration of $4 \mu \mathrm{g}$ bFGF simultaneously with MPTP treatment or 1 week after initiation of the MPTP lesion caused a notable reappearance of ipsilateral TH-IR fibers adjacent to the implant but not on the contralateral side. This morphological recovery may be due either to a regrowth of degenerated nerve terminals and/or collateral sprouting of intact terminals. Moreover, a reexpression of TH-IR without any concomitant growth events might also account for this observation. It can be excluded, however, that the reappearance of TH-IR fibers resulted from the ingrowth of noradrenergic nerves since the noradrenaline content was unaltered. These morphological observations are comparable to those obtained after grafting adrenal medullary tissue in MPTP-treated mice (Bohn et al., 1987) and monkeys (Fiandaca et al., 1988).

The evaluation of this bFGF-induced ipsilateral enhancement of TH-IR fibers turned out to be far more complex when looking at parameters concerning the DA metabolism (see Table 4). Interestingly, the DA content could be restored on both sides to the same level, that is, to $45 \%$ of controls. The contralateral elevation of DA content referred rather to the potency of compensatory mechanisms in this system than pointing at the existence of a diffusible factor. The DA content of the untreated left side initially appeared to be incompatible with the lack of TH-IR fibers. As the measured DA content represents the product of synthesis, degradation, storage, and release, we assumed an alteration of at least one of these parameters on the left as compared to the right side. We therefore looked for side differences in the TH content as well as in the specific TH activity and DOPAC content. The differences in the TH protein content assessed by immunoblots indicating that striata ipsilateral to bFGF treatment contained more $\mathrm{TH}$ than contralateral striata were in line with the TH-IR being present only in the ipsilateral striata. Despite the apparent lower TH content on the contra-

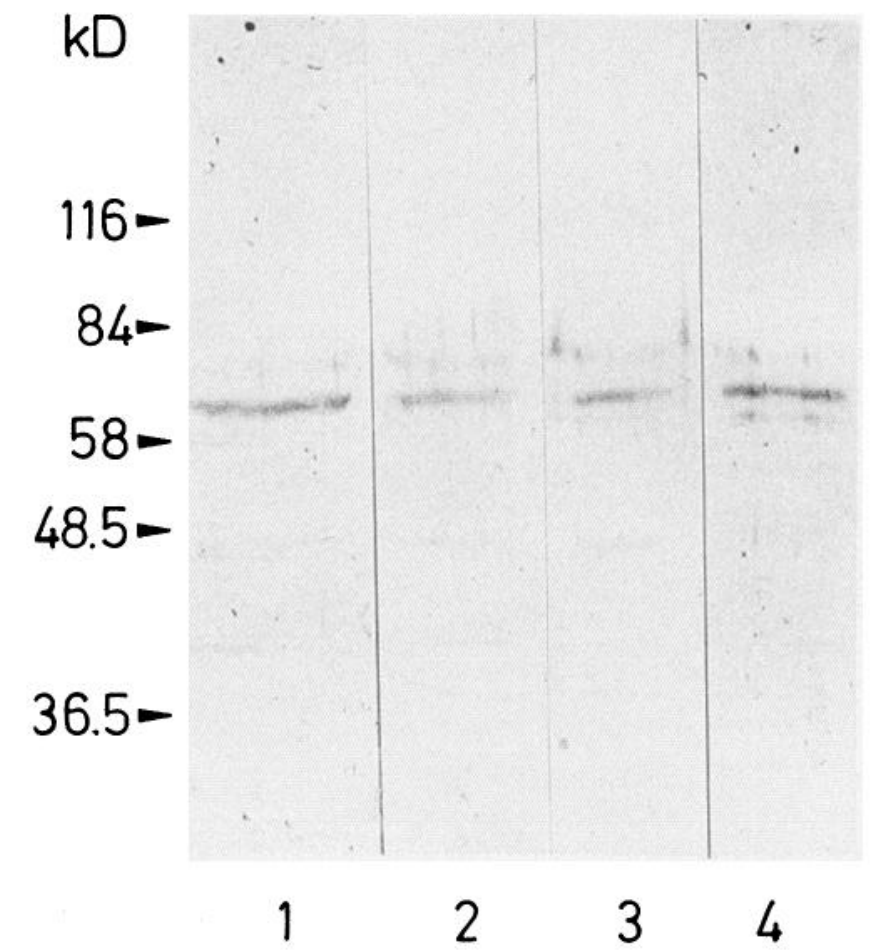

Figure 3. Amounts of striatal TH protein semiquantitatively visualized by the intensity of staining. Prior to immunoblotting striatal homogenates with identical protein content were separated by SDS electrophoresis. TH protein content of the right striatum (implant side) in MPTP/cytochrome c-treated mice (lane 2) is drastically reduced compared to control mice (cytochrome c; lane 1). In MPTP-treated mice, TH content appears to be increased ipsilateral to bFGF application (lane 4 ), whereas on the contralateral side, the $\mathrm{TH}$ content is still decreased (lane 3).

lateral side, TH activity was equal on both sides. These results in conjunction with the evidence that DOPAC levels are higher in the contralateral striata suggest a higher molar TH activity on that side. The increase of the molar TH activity in striata contralateral to bFGF treatment may occur as a compensatory intrinsic mechanism (Acheson et al., 1980) to provide equal levels of the transmitter DA in both striata.

As mentioned above, the recovery in regard to morphology, i.e., partial reappearance of TH-IR fibers, in this lesion paradigm

Table 4. Synopsis of results comparing behavior of right and left striatal DA metabolism

\begin{tabular}{llll} 
Right striatum & & Left striatum & \\
\hline [DA] & $=$ & {$[D A]$} & (Table 1) \\
TH-IR fibers & $>$ & TH-IR fibers & (Figs. 1, 2) \\
{$[$ TH] } & $>$ & {$[$ TH] } & (Fig. 3) \\
TH activity & $=$ & TH activity & (Table 2) \\
[DopAC] $_{\text {Molar TH activity }}^{a}$ & $<$ & [Dopac] & (Table 3) \\
Molar TH activity &
\end{tabular}

Data were obtained 2 weeks after implantation of gel foam, containing $4 \mu \mathrm{g}$ bFGF, to the right striatum of MPTP treated mice. For details refer to the indicated tables and figures.

${ }^{a}$ Considering data from $\mathrm{TH}$ immunoblots, which indicated that right striata contain more TH than left striata. In context with the other data (see above), we assume that the molar TH activity is higher in left than in right striata. 

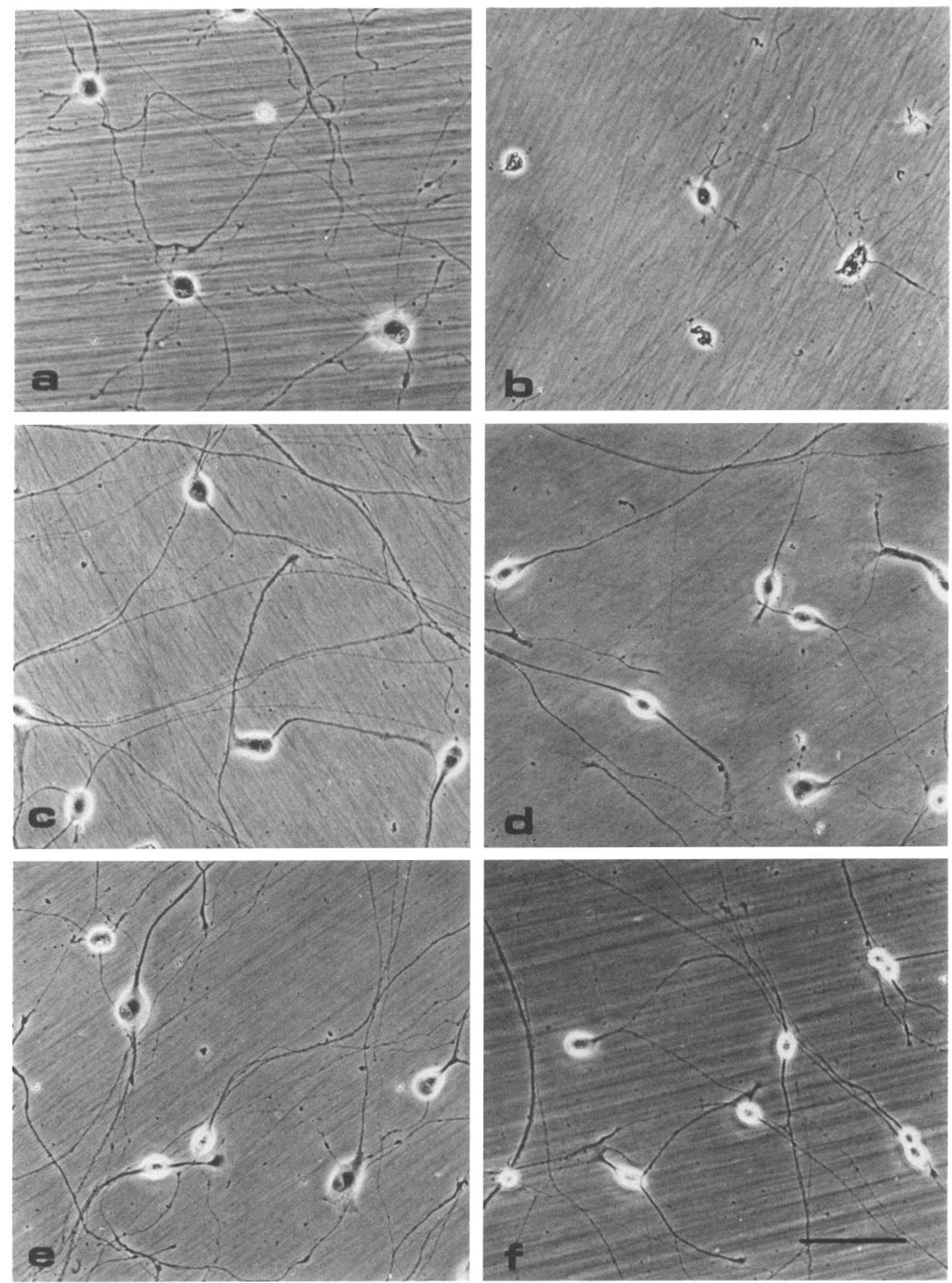
indicates that the effects of adrenal medulla grafts can be mimicked by application of a single neurotrophic protein, bFGF. Trophic mechanisms have previously been proposed to be implied in graft-mediated morphological or functional recovery (Bohn et al.. 1987: Fiandaca et al., 1988; Pezzoli et al., 1988). This suggestion was based on the observation that in many cases the poor survival of grafts was not consistent with its putative curative effects. This raised doubts about whether transplanted chromaffin cells were actually able to substitute for the lost striatal dopamine, a mechanism which had long been regarded as being responsible for the promotion of functional recovery. The rationale for our conjecture that bFGF might be involved in graft-related recovery was provided by evidence that bFGF (1) is present in chromaffin tissue (Blottner et al., 1989; Westermann et al., 1990) and (2) exerts neurotrophic activities in wo as shown in various lesion models (Anderson et al., 1988; Blotiner et al., 1989; Otto et al., 1989).

Supposedly, our data result from a combination of events including sprouting of fibers, cell survival, and regulatory processes in DA metabolism. Certainly, our data do not permit the conclusion that bFGF is the agent directly responsible for these effects. bFGF might have acted by inducing proliferation of astroglial cells, as previously described after partial fimbriafornix transection and ventricular infusion of bFGF (Barotte et al. 1989). However. prerequisites for a proliferative response of astroglial cells to bFGF have not been fully explored. Thus, bFGF may not or only moderately increase numbers of astrocytes over extended periods of time in vitro (Walicke and Baird, 1988). or. as reported by others, it may induce massive prolifcration and maturation (Weibel et al., 1985: Perraud et al., 1988). Astroglia, in turn, might have facilitated recovery (Kesslak et al.. 1986), for example, secreting neurotrophic molecules (Assouline et al. 1987). It is also conceivable that bFGF can modulate the output of injury-induced or synergistically acting neurotrophic activities (Nieto-Sampedro et al., 1983) or molccules provided by inflammatory responses. Macrophages have been repeatedly suspected to play a regulatory role in the production of neurotrophic factors by neuronal or non-neuronal cells (Giulian and Lachman, 1985; Lindholm et al., 1987). In our study. macrophage-like cells invading the gel foam implant (c. Figs. 1c, d, and 2) were observed inconsistently and independently of the treatment. Studies are in progress to investigate in detail the possible responses of astroglial, vascular, and bloodborne cells to bFGF in MPTP-lesioned mice.

Interestingly, the neurotrophic activities of the wound fluid collected from cytochrome $\mathrm{c}$ - and bFGF-lreated mice contained approximately equal levels of neurotrophic activities promoting embryonic chick ciliary ganglion survival and possessed strong neurite-promoting activity. Both were not significantly inhibited by the anti-bFGF-IgG. It is unlikely that the antibodies might not have recognized mouse bFGF given the extensive homologies of the mammalian bFGF sequences (Lobb, 1988). Although bFGF is increased in CNS wounds (Finklestein et al., 1988). it is conceivable that the cytochrome c- or bFGF-containing gel foams in our experiments had taken up bFGF-mediated. CG-directed trophic agents.
bFGF has widespread distribution in the CNS (Janet et al.. 1987), and it may not be inferred from our findings that this protein is the physiological agent for nigrostriatal neurons. Even so, the recent purification of a basic $14 \mathrm{~K}$ neurotrophic factor promoting in vitro survival and transmitter expression of embryonic mesencephalic DA neurons (Dal Toso et al. 1988) and the observation that bFGF mimics these effects (Ferrari ct al.. 1989) would be compatible with the notion of bFGF being a candidate factor in this neuronal system.

In conclusion. bFGF has been shown in this study to reverse to some extent the chemical and morphological deficits within the nigrostriatal dopaminergic system which might be of relevance to Parkinson's disease. It upens perspectives towards the possibility of eventually replacing brain grafts by defined neurotrophic and other factors and studying in more detail the local regulation of bFGF in the striatum of the normal and parkinsonian brain.

\section{References}

Acheson AL, Zigmond MJ. Stricker EM (1980) Compensatory increase in tyrosine hydroxylase activity in rat brain after intraventricular injections of 6-hydroxydopamine. Science 207:537-540.

Anderson KJ. Dam D. Lee S. Cotman CW (1988) Basic fibroblast growth factor prevents death of lesioned cholinergic neurons in vivo. Nature 332:360-361

Assouline JG, Bosch P, Lim R. Kim IS. Jensen R. Pantazis NJ (1987) Rat astrocytes and Schwann cells in culture synthesize nerve growth factor-like neurite-promoling factors. Dev Brain Res 31:103-118.

Ballard PA, Tetrud JW, Langston JW (1985) Permanent human parkinsonism due to 1-methyl-4-phenyl-1.2.3.6-tetrahydropyridine (MPTP): seven cases. Neurology 35:949-956.

Barotte C. Eclancher F. Ebel A. Labourdette (i. Sensenbrenner M. Will B (1989) Effects of basic fibroblast growth factor (bFGF) on choline acetyltransferase activity and astroglial reaction in adult rats after partial fimbria transection. Neurosci Lett 101:197-202.

Becker JB. Freed WJ (1988) Adrenal medulla grafts enhance functional activity of the striatal dopamine system following substantia nigra lesions. Brain Res 462:401-406.

Bernheimer H. Birkheimer W, Hornykiewit/ O. Jellinger K. Seidelber ger $F$ (1973) Brain dopamine and the syndromes of Parkinson and Huntington. J Neurol Sci 20:415-455.

Bing G, Jiau S, Noller MFD, Hansen JT. Gash DM (1988) Cografts of adrenal medulla with peripheral nerve in the dopamine-denervated rat striatum. Soc Neurosci Abstr 14:735.

Björklund A, Stenevi U (1979) Regeneration of monoamınerglc and cholinergic neurons in the mammalian central nervous system. Physiol Rev 59:62-100.

Blottner D, Westermann R, Grothe C. Böhlen P. Unsicker K (1989) Basic fibroblast growth factor in the adrenal gland: possible trophic role for preganglionic neurons in vivo. Eur J Neurosci 1:471-478.

Bohn MC, Cupit L. Marciano F. Gash DM (1987) Adrenal medulla grafts enhance recovery of striatal dopaminergic fibers. Science 237: 913-916.

Bottenstein JE, Skaper SD, Varon SS. Sato (jH (1980) Selective survival of neurons from chick embryo sensory ganglionic dissociates utilizing serum-free supplemented medium. Exp Cell Res 125:183190.

Burns RS, Chiuch CC. Markey SP. Ebert MH. Jacobowitz DM. Kopin IJ (1983) Primate model of Parkinson's disease: selective destruetion of substantia nigra pars compacta dopaminergic neurons by N-methyl-4-phenyl-1,2.3.6-tetrahydropyridine. Proc Natl Acad Sci USA 80:4546-4550.

Burns RS. LeWitt PA. Ebert MH. Pakkenberg H. Kopin IJ (1985) The clinical syndrome of striatal dopamine deficiency. Parkinsonism in-

Figlife 4 . Neurotrophic activities eluted from gel foam tested on neurons from embryonic chick ciliary ganglia. bFGF-dependent survival (a) is markedly inhibited by the addition of anti-bFGF-IgG $(b)$. Eluates from cytochrome $c(c)$ or bFGF gel foam implants $(e)$ maintained sinilat neuron numbers: neither activity was inhibited by the addition of anti-bFGF-IgG (d, cytochrome c; $f, b F G F)$. Scale bar. $50 \mu \mathrm{m}$. 
duced by 1-methyl-4-phenyl-1,2,3,6-tetrahydropyridine (MPTP). N Engl J Med 312:1418-1421.

Dal Toso R, Giorgi O, Soranzo C, Ferrari G, Favaron M, Benvegnù D, Presti D, Vicini S, Toffano G, Azzone GF, Leon A (1988) Development and survival of neurons in dissociated fetal mesencephalic serum-free cell cultures. I. Effects of cell density and of an adult mammalian striatal-derived neuronotrophic factor (SDNF). J Neurosci 8:733-745.

Dunnett SB, Björklund A, Stenevi U, Iversen SD (1981) Behavioural recovery following transplantation of substantia nigra in rats subjected to 6-OHDA lesions of the nigrostriatal pathway. II. Bilateral lesions. Brain Res 229:457-470.

Dunnett SB, Björklund A, Schmidt RH, Stenevi U, Iversen SD (1983) Behavioural recovery in rats with unilateral 6-OHDA lesions following implantation of nigral cell suspensions in different forebrain sites. Acta Physiol Scand 522:29-37.

Ferrari G, Minozzi M-C, Toffano G, Leon A, Skaper SD (1989) Basic fibroblast growth factor promotes the survival and development of mesencephalic neurons in culture. Dev Biol 133:140-147.

Fiandaca MS, Kordower JH, Hansen JT, Jiao S-S, Gash DM (1988) Adrenal medullary autografts into the basal ganglia of Cebus monkeys: injury-induced regeneration. Exp Neurol 102:76-91.

Finklestein SP, Apostolides PJ, D'Amore PA, Domesick VB, Klagsbrun $M$ (1988) Increased levels of basic fibroblast growth factor (bFGF) following focal brain injury. Soc Neurosci Abstr 443.12.

Freed WJ, Morisha M, Spoor HE, Hoffer BJ, Olson L, Seiger A, Wyatt RJ (1981) Transplanted adrenal chromaffin cells in rat brain reduce lesion-induced rotational behaviour. Nature 292:315-319.

Freed WJ, Karoum F, Spoor HE, Olson L, Morisha JM, Wyatt RJ (1983) Catecholamine content of intracerebral adrenal medulla grafts. Brain Res 269:184-189.

Freed WJ, Cannon-Spoor H, Krauthamer E (1986) Intrastriatal adrenal medulla grafts in rats. J Neurosurg 65:664-670.

Gibson MJ, Krieger DT (1985) Neuroendocrine brain grafts in mutant mice. Trends Neurosci 8:331-334.

Giulian D, Lachman LB (1985) Interleukin-1 stimulation of astroglial proliferation after brain injury. Science 228:487-499.

Gospodarowicz D, Neufeld G, Schweigerer L (1986) Molecular and biological characterization of fibroblast growth factor, an angiogenic factor which also controls the proliferation and differentiation of mesoderm and neuroectoderm derived cells. Cell Differ 19:1-17.

Gupta M, Gupta BK, Thomas R, Brümmer V, Sladek RJ Jr, Felten DL (1986) Aged mice are more sensitive to 1-methyl-4-phenyl-1,2,3,6tetrahydropyridine treatment than young adults. Neurosci Lett 70 : 326-331.

Hallman H, Lange J, Olson L, Strömberg I, Jonsson G (1985) Neurochemical and histochemical characterization of neurotoxic effects of 1-methyl-4-phenyl-1,2,3,6-tetrahydropyridine on brain catecholamine neurones in the mouse. $J$ Neurochem 44:117-127.

Hansen JT, Kordower JH, Fiandaca MS, Jiao S-S, Notter MFD, Gash DM (1988) Adrenal medullary autografts into the basal ganglia of Cebus monkeys: Graft viability and fine structure. Exp Neurol 102: 65-75.

Hawkes R, Niday I, Gordon J (1982) A dot-immunobinding assay for monoclonal and other antibodies. Anal Biochem 119:142-147.

Hefti F, Weiner WJ (1988) Adaptive changes in central dopaminergic neurons after injury. Effects of drugs. In: Pharmacological approaches to the treatment of brain and spinal cord (Stein DG, Sabel BA, eds). pp 103-109. New York: Plenum.

Heikkila RE, Hess A, Duvoisin RC (1984) Dopaminergic neurotoxicity of 1-methyl-4-phenyl-1,2,3,6-tetrahydropyridine in mice. Science 224:1451-1453.

Hofmann HD, Unsicker K (1987) Characterization and partial purification of a novel neuronotrophic factor from bovine seminal vesicle. J Neurochem 48:1425-1433.

Janet T, Miehe M, Pettmann B, Labourdette G, Sensenbrenner M (1987) Ultrastructural localization of fibroblast growth factor in neurons of rat brain. Neurosci Lett 80:153-157.

Jenner P, Nadia MT, Rupniak SR, et al (1984) 1-Methyl-4-phenyl1,2,3,6-tetrahydropyridine-induced parkinsonism in the common marmoset. Neurosci Lett 50:85-90.

Kesslak JP, Nieto-Sampedro M, Globus J, Cotman CW (1986) Tranplants of purified astrocytes promote behavioural recovery after frontal cortex ablation. Exp Neurol 92:377-390.
Laemmli UK (1970) Cleavage of structural proteins during assembly of the head of bacteriophage T4. Nature 227:680-685.

Langston JW, Irwin I (1986) MPTP: current concepts and controversies. Clin Neuropharmacol 9:485-507.

Lindholm D, Heumann R, Meyer M, Thoenen H (1987) Interleukin-1 regulates synthesis of nerve growth factor in non-neuronal cells of rat sciatic nerve. Nature 330:658-659.

Lobb RR (1988) Clinical applications of heparin-binding growth factors. Eur J Clin Invest 18:321-336.

Lobb RR, Fett JW (1984) Purification of two distinct growth factors from bovine neural tissue by heparin affinity chromatography. Biochemistry 23:6295-6299.

Marsden CD, Jenner PG (1987) The significance of 1-methyl-4-phenyl-1,2,3,6-tetrahydropyridine. Ciba Found Symp 126:239-256.

Morrison RS, Sharma A, DeVellis J, Bradshaw RA (1986) Basic fibroblast growth factor supports the survival of cerebral cortical neurons in primary culture. Proc Natl Acad Sci USA 83:7537-7541.

Müller T, Unsicker K (1981) High-performance liquid chromatography with electrochemical detection as a highly efficient tool for studying catecholaminergic systems. I. Quantification of noradrenaline, adrenaline and dopamine in cultured adrenal medullary cells. $\mathrm{J}$ Neurosci Methods 4:39-52.

Nieto-Sampedro M, Manthorpe M, Barbin G, Varon S, Cotman CW (1983) Injury-induced neuronotrophic activity in adult rat brain: correlation with survival of delayed implants in the wound cavity. J Neurosci 3:2219-2229.

Otto D, Unsicker K, Grothe C (1987) Pharmacological effects of nerve growth factor and fibroblast growth factor applied to the transectioned sciatic nerve on neuron death in adult rat dorsal root ganglia. Neurosci Lett 83:56-160.

Otto D, Frotscher M, Unsicker K (1989) Basic fibroblast growth factor and nerve growth factor administered in gel foam rescue medial septal neurons after fimbria fornix transection. J Neurosci Res 22:83-91.

Patel-Vaidya U, Wells MR, Freed WJ (1985) Survival of dissociated adrenal chromaffin cells of rat and monkey transplanted into rat brain. Cell Tissue Res 240:281-285.

Perlow MJ, Freed WJ, Hoffer BJ, Seiger A, Olson L, Wyatt RJ (1979) Brain grafts reduce motor abnormalities produced by destruction of nigrostriatal dopamine system. Science 204:643-647.

Perraud F, Besnard F, Pettmann B, Sensenbrenner M, Labourdette G (1988) Effects of acidic and basic fibroblast growth factors (aFGF and $b F G F$ ) on the proliferation and the glutamine synthetase expression of rat astroblasts in culture. Glia 1:124-131.

Pezzoli G, Fahn S, Dwork A, Truong DD, de Yebenes JG, JacksonLewis V, Herbert J, Cadet JL (1988) Non-chromaffin tissue plus nerve growth factor reduces experimental parkinsonism in aged rats. Brain Res 459:398-403.

Ricaurte GA, Langston JW, Delanney LE, Irwin I, Peroutka SJ, Forno LS (1986) Fate of nigrostriatal neurons in young mature mice given 1-methyl-4-phenyl-1,2,3,6-tetrahydropyridine: a neurochemical and morphological reassessment. Brain Res 376:117-124.

Stenevi U, Björklund A, Kromer LF (1984) Use of CNS implants to promote regeneration of central axons across denervating lesions in the adult rat brain. In: Neural transplants (Sladek JR Jr, and Gash DM, eds). New York: Plenum.

Strömberg I, Herrera-Marschitz M, Hultgren L, Ungerstedt U, Olson L (1984) Adrenal medullary implants in the dopamine-denervated rat striatum. I. Acute catecholamine levels in grafts and host caudate as determined by HPLC-electrochemistry and fluorescence histochemical image analysis. Brain Res 297:41-51.

Strömberg I, Herrera-Marschitz M, Ungerstedt U, Ebendal T, Olson L (1985) Chronic implants of chromaffin tissue into the dopaminedenervated striatum. Effects of NGF on graft survival, fiber growth and rotational behaviour. Exp Brain Res 60:335-349.

Sundström E, Strömberg I, Tsutumi T, Olson L, Jonsson G (1987) Studies on the effects of 1-methyl-4-phenyl-1,2,3,6-tetrahydropyridine (MPTP) on central catecholamine neurons in C57BL/6 mice. Comparison with three other strains of mice. Brain Res 405:26-38.

Sundström E, Luthman J, Goldstein M, Jonsson G (1988) Time course of MPTP-induced degeneration of the nigrostriatal dopamine system in C57BL/6 mice. Brain Res Bull 21:257-263.

Towbin H, Stähelin T, Gordon J (1979) Electrophoretic transfer of proteins from polyacrylamid gels to nitrocellulose sheets. Procedure and some applications. Proc Natl Acad Sci USA 76:4350-4354. 
Unsicker K. Blottner D, Gehrke D, Stögbauer F, Westermann R. Fischer-Colbric R, Winkler H, Böhlen P (1987a) Neuronotrophic factors in adrenal medullary cells: development, release and molecular characteristics. Soc Neurusci Abstr 444.3.

Unsicker K, Reichert-Preibsch H, Schmidt R, Pettmann B, Labourdette G. Sensenbrenner M (1987b) Astroglial and fibroblast growth factors have neurotrophic functions for cultured peripheral and central nervous system neurons. Proc Natl Acad Sci USA 83:817-821.

Unsicker K, Gehrke D, Grothe C, Heymann D, Stögbauer F. Westermann R (1989) Characterization of trophic factors stored and secreted by neurons. In: Molecular aspects of development and aging of the nervous system (Lauder J et al., eds). New York: Plenum.

Walicke PA, Baird A (1988) Neurotrophic effects of basic and acidic fibroblast growth factors are not mediated through glial cells. Dev Brain Res 40:71-79.

Walicke P, Cowan WM, Ueno N, Baird A, Guillemin R (1986) Fibroblasi growth factor promotes survival of dissociated hippocampal neurons and enhances neurite extension. Proc Natl Acad Sci USA 83:3012-3016.

Weibel M, Pettmann B, Labourdette G, Miehe M, Bock E, Sensenbrenner M (1985) Morphological and biochemical maturation of rat astroglial cells grown in a chemically defined medium: influence of an astroglial growth factor. Int J Dev Neuroscience 3:617-630.

Westermann R, Johannsen M, Unsicker K, Grothe C (1990) Basic fibroblast growth factor (bFGF) immunoreactivity is present in chro maffin granules. J Neurochem (in press). 